\title{
ERRATUM
}

Jose V. Carbonell • Patricia Contreras •

Leire Carbonell · Jose Luis Navarro

\section{Pectin methylesterase activity in juices from mandarins, oranges} and hybrids

Published online: 10 January 2006

(C) Springer-Verlag 2005

\section{Eur Food Res Technol (2005) 222:83-87 \\ DOI 10.1007/s00217-005-0043-9}

Due to an unfortunate error the name of the authors' institute was missing. The correct author details are given here.

The online version of the original article can be found at http://dx.doi.org/10.1007/s00217-005-0043-9.

J. V. Carbonell $(\bowtie) \cdot$ P. Contreras · L. Carbonell · J. L. Navarro Instituto de Agroquímica y Technología de Alimentos, CSIC, Apdo 73, Burjassot,

Valencia, 46100 Spain

e-mail: jcarbonell@iata.csic.es

Tel.: +34-96-390-00-22

Fax: +34-96-363-63-01 